\title{
- An integrated hydrological and hydraulic modelling 2 approach for the flood risk assessment over Po river basin.
}

${ }_{4}$ Rita Nogherotto, 1 Adriano Fantini, Francesca Raffaele, Fabio Di

5 Sante, Francesco Dottori, Erika Coppola, and Filippo Giorgi ${ }^{1}$

${ }_{6}{ }^{1}$ International Centre for Theoretical Physics,Trieste, Italy

$7{ }^{2}$ European Commission, Joint Research Centre, Ispra, Italy

\section{Abstract}

Identification of flood prone areas is instrumental for a large number of applications, ranging from engineering to climate change studies, and provides essential information for planning effective emergency responses. In this work we describe an integrated hydrological and hydraulic modeling approach for the assessment of flood-prone areas in Italy and we present the first results obtained over the Po river (Northern Italy) at a resolution of 90m. River discharges are obtained through the hydrological model CHyM driven by GRIPHO, a newlydeveloped high resolution hourly precipitation dataset. Runoff data is then used to obtain Synthetic Design Hydrographs (SDHs) for different return periods along the river network. Flood hydrographs are subsequently processed by a parallelized version of the CA2D hydraulic model to calculate the flow over an ad hoc re-shaped HydroSHEDS digital elevation model which includes information about the channel geometry. Modeled hydrographs and SDHs are compared with those obtained from observed data for a choice of gauging stations, showing an overall good performance of the CHyM model. The flood hazard maps for return periods of 50, 100, 500 are validated by comparison with the official flood hazard maps produced by the River Po Authority (Adbpo) and with the Joint Research Centre's (JRC) pan-European maps. The results show a good agreement with the available official national flood maps for high return periods. For lower return periods the results and less satisfactory but overall the application suggests strong potential of the proposed approach for future applications.

Keywords: Flood hazard; Flood mapping; CHyM hydrologic model; CA2D hydraulic model. 


\section{Introduction}

The last few decades have seen increased interest towards the study of floods, their consequences and the development of measures to reduce their impact. Flood hazard maps are designed to indicate the probability and/or magnitude of inundations over a given area and are used as an important decision making tool for multiple purposes ranging from infrastructure development to disaster response planning. This is also endorsed by the European Union Flood Risk Management Directive (European Commission, 2007), which mandate is the development of flood hazard maps for exposed territories, showing the potential consequences associated with different flood scenarios, in order to guarantee an effective basis for technical, financial and political decisions regarding the flood risk management. Until recently, flood hazard maps were only available for few regions of the globe, and with coarse resolutions, due to the high data and computational requirements of the hydraulic models employed in their production (Moel et al., 2009). The increase of computational power and the availability of remotely sensed datasets, however, have made the application of flood models with higher resolution (less than $1 \mathrm{~km}$ ) possible even over large domains (Wood et al., 2011).

Different methods to quantify flood hazard can be employed, resulting in different types of flood maps (Moel et al., 2009). Within the different approaches, the common steps are essentially two: 1) the estimation of the discharges for specific return periods and 2) the combination of the discharges with a digital elevation model (DEM) for the creation of the flood map.

For limited area gauged basins, where discharges data are available, the first step can be accomplished by using frequency analyses on discharge records and fitting extreme values distributions (e.g. Te Linde et al., 2008). For larger domains, flood information can be extrapolated to ungauged areas using regionalisation techniques (e.g. Merz and Blöschl, 2005) or by using hydrological models to calculate discharges (Bárdossy, 2007; Khan et al., 2011). These models require spatially explicit meteorological (e.g. temperature, precipitation, evaporation, radiation), soil, and land cover data as input and they solve the water balance for each geographical unit for each time step, to yield the discharges for all river stretches. The strength of this approach is not only the applicability over ungauged regions, but also the possibility of assessing the impact of changes in climate and/or land cover on floods. The second step is usually accomplished by using hydraulic models specifically designed for solving channel and floodplain hydraulic routing. Historically, this was usually performed by modeling fluvial hydraulics with one-dimensional finite difference solutions of the full St. Venant equations (see Fread, 1985; Samuels, 1990), using models such as MIKE11 (Havnø et al., 1995) and HEC-RAS (Brunner, 2002). These schemes describe the river channel and floodplain as a series of cross sections perpendicular to the flow and estimate average velocity and water depth at each cross section. Despite the successful validation of flood inundation extent using low resolution satellite imagery (Bates et al., 1997), the one-dimensional schemes have the drawbacks of being computationally expensive and the areas between the cross sections are not explicitly represented (Samuels, 1990; Bates and De Roo, 2000). Thanks to 
the increasing availability of high resolution Digital Elevation Models (DEM) for floodplain areas, two-dimensional distributed models have been developed to allow a better conjunction with the elevation of the channel and of the floodplain surface, and to guarantee the calculation of the water depth and depth-averaged velocity at each computational node at each time step. Examples of such two-dimensional schemes are LISFLOOD-FP (Bates and De Roo, 2000), RBFVM-2D (Zhao et al., 1994) and TELEMAC-2D (Galland et al., 1991). These physically based models solve the Shallow Water Equations (SWEs) and, due to the recent advancement in parallel computing techniques, can be applied over large areas at high resolution. In recent years, a new approach was developed which employs cellular automata (CA) algorithms instead of directly solving the SWEs for each interface: for each timestep, the new state of a cell depends only on the state of the neighbouring cells at the previous timestep, according to a set of rules. This technique allows to model complex physical systems using simple operational rules (Wolfram, 1984), drastically reducing the computational requirements compared to physically based models. These algorithms are therefore well suited for parallel computation and have been successfully used to simulate many types of water related problems (e.g. Coulthard et al., 2007; Krupka et al., 2007; Austin et al., 2013).

An example is the CA2D model developed by Dottori and Todini (2011). The CA2D model uses a 2D cellular automata approach and the equations developed for the LISFLOOD-FP model (Bates et al. (2010)) to make high resolution simulations possible at continental and global scale (Dottori et al. (2016d)).

In this study we describe an integrated hydrological and hydraulic modelling approach which uses the Cetemps Hydrological Model (CHyM, Coppola et al. (2007)) and a modified version of the CA2D hydraulic model, hereinafter referred to as CA2D par. CA2D par includes a parallel algorithm with the physics of the CA2D model but that can be run with multiple processors to further speed up the computation. Furthermore, to better represent river flow and flooding processes, we produced a re-shaped digital elevation model which includes information about the channel geometry by simulating a "digging" assuming that discharges associated to return periods of 1.5 years produce no floods as they represent the conveyance capacity of the river channel. This model has been used over the entire Italian territory. In the present work we focus on the results obtained over the Po river, which is the river with the largest average daily discharge in the Italian peninsula and in whose basin $40 \%$ of the gross domestic product of Italy is produced (Montanari, 2012).

In Section 2 we will describe the observational and modelled data and the method applied for flood hazard assessment of the western basin of the river Po. Section 3 will present the results, by means of a validation of the obtained SDHs, a validation of the hazard maps against observations and against existing flood hazard maps. 


\section{Data and methods}

The approach proposed herein assumes that large scale flood hazard maps can be derived from an ensemble of small scale simulations of flood processes, arranged to cover the entire river network, as previously demonstrated in literature (Alfieri et al., 2013, 2014; Dottori et al., 2016d). The procedure is composed by the following steps: 1) the hydrological simulations are setup and calibrated for the production of a long-term discharge time series; 2) the designed hydrographs are derived for different selected return periods; 3) the floodplain hydraulic simulations are performed and the flood maps for each return period are produced. These three different steps will be described in detail in the following subsections.

\subsection{The observational data and the hydrological model CHyM}

Hydrological simulations are performed using the CETEMPS Hydrological Model (CHyM) (Coppola et al., 2007), the distributed hydrological model developed by the CETEMPS Center of Excellence at the University of L'Aquila. CHyM uses information from a Digital Elevation Model (DEM) and produces a D8 connected river network, using cellular automata algorithms to resolve local singularities and no-flow points (Coppola et al., 2007).

Input precipitation from various sources can be assimilated, including gridded precipitation from observations and models. Discharge is routed through each grid cell using continuity and momentum equations based on the kinematic shallow water approximation of Lighthill and Whitham (1955). CHyM is specifically designed for Italian river catchments and has been widely tested for a variety of regions across Italy, and in particular for the Po basin (Coppola et al., 2014; Verdecchia et al., 2009; Tomassetti et al., 2005b). For this study, nine separate domains are simulated, with a resolution varying between 300 and $900 \mathrm{~m}$ (Fig. 1). The domains are matching the operational domains simulated by CETEMPS to forecast potential floods using stress indexes (Tomassetti et al., 2005a; Verdecchia et al., 2008), but they are higher resolution because the HydroSHEDS Digital Elevation Model is used (Lehner et al., 2013), which is specifically conditioned for hydrological usage. The choice of the DEM is crucial to ensure correct river routing especially in large, flat areas such as the Po plain. The simulations span the period 2001-2016 and are driven by the newly-developed hourly precipitation dataset GRIPHO (Fantini et al., 2019; Fantini, 2019), which includes qualitycontrolled data from 3712 precipitation stations covering all of Italy. MM5 weather forecasts (Grell et al., 1994), operationally in use at CETEMPS for more than 20 years (see e.g. Bianco et al., 2006), are employed to fill data gaps in GRIPHO.

Further information on the hydrological simulations used for this study, including validation against discharge observations, can be found in Fantini (2019, chapters 4 and 5). 


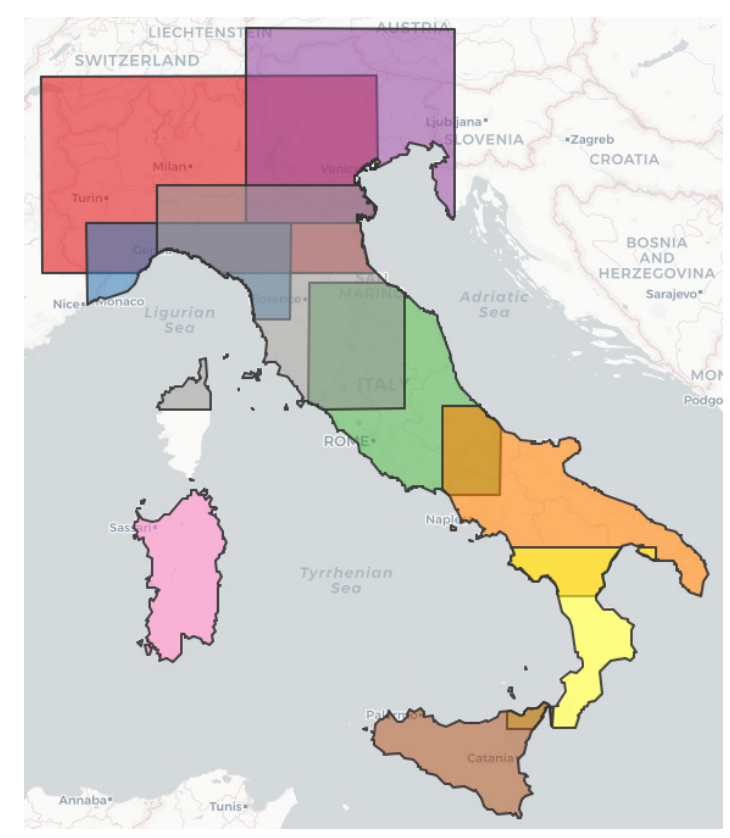

Figure 1: The nine domains on which the CHyM model is run operationally.

\subsection{Processing the hydrological inputs: the Synthetic Designed Hydrographs (SDHs)}

The statistical procedure applied in this study is based on the work of Maione et al. (2003), who performed a Flood Frequency Analysis (FFA) starting from observational data for the Po river basin. The aim is to obtain curves describing the typical discharge timeseries of the event at that river point for the given Return Period. These $Q_{R P}(t)$ curves will be called Synthetic Design Hydrographs (SDHs) and they represent the discharge $(Q)$ of a typical extreme event as a function of the Return Period $(R P)$ and the time $(t)$. SDHs are estimated and used as input data for the hydraulic model in order to predict the corresponding maximum flood inundation extent and depth (see subsection 2.3). Simulations were performed using observational data described in subsection 2.1 and processed to derive synthetic flood hydrographs throughout a statistical analysis of the Flow Duration Frequency (FDF) reduction curves $Q_{D}(R P)$ (Maione et al., 2003) . These curves represent the typical discharge with Return Period $R P$ averaged over any duration $D$ around the flood peak. For each station along the river network $Q_{D}(R P)$ can be calculated from statistical analyses of historical hydrographs. Similarly to the work of Maione et al. (2003) we used the empirical relationship proposed by NERC (1975) defining the reduction ratio $\left(\epsilon_{D}\right)$, which is the ratio of the FDF 
and the peak flood discharge $\left(Q_{0}(R P)\right)$, as follows:

$$
\epsilon_{D}(R P)=\frac{Q_{D}(R P)}{Q_{0}(R P)} .
$$

In this work we assume $\epsilon_{D}$ is independent on the return period, which occurs for medium-large catchments, as done by Maione et al. (2003) and Alfieri et al. (2013). When performing the calculation of the FDF around each historical flood peak, the centre of the duration window of width $\mathrm{D}$ is chosen as to maximise the average computed discharge $Q_{D}$ :

$$
F D F=Q_{D}=\frac{1}{D} \max \int_{t}^{t+D} Q(\tau) d \tau
$$

where $t$ and $\tau$ represent time. The shape of the final synthetic hydrograph will be determined by the peak-duration ratio $r_{D}$ that is the ratio of the time before the peak and the total duration $D$ of the averaging window. The smaller the $r_{D}$, the more skewed the hydrograph will be towards steeper (flatter) rising (falling) limbs of the hydrograph. Centring on $t=0$ the peak flood timing, the two limbs of the hydrograph can be described as:

$$
\begin{gathered}
\int_{-r_{D} D}^{t=0} Q(\tau)=r_{D} D Q_{D}(R P) \\
\int_{t=0}^{\left(1-r_{D}\right) D} Q(\tau)=\left(1-r_{D}\right) D Q_{D}(R P),
\end{gathered}
$$

and

where $Q_{D}(R P)$ is the typical FDF curve for the Return Period $R P$. The construction of the SDH is performed imposing that the maximum discharges for each duration coincides with the value obtained from the FDF curves, in a given duration $D$ for each value of the return period $R P$. Thus the $\mathrm{SDH}$ is obtained differentiating with respect to the duration $D$, obtaining for the falling limb:

$$
S D H=Q_{t}(R P)=\frac{d /\left.d D\left[\left(1-r_{D}\right) D Q_{D}(R P)\right]\right|_{D=D(t)}}{d /\left.d D\left[\left(1-r_{D}\right) D\right]\right|_{D=D(t)}}
$$

where $t=\left(1-r_{D}\right) D$.

The maximum flood discharge $Q_{0}(R P)$ for any given Return Period $R P$ must then be calculated by fitting an appropriate extreme distribution. Following Alfieri et al. (2015) and Maione et al. (2003), we chose the Gumbel distribution, so that:

$$
Q_{0}(R P)=u-\alpha \ln \left[-\ln \left(1-\frac{1}{R P}\right)\right],
$$

where the parameters $u$ and $\alpha$ are estimated from the fit, and are used for the differentiation of the equation 5. The equation, representing the falling limb of the SDH, allows us to calculate a typical flood event discharge timeseries for any location and Return Period, starting only from the timeseries of yearly maximum discharges. Further details about the procedure and its implementation can be found in Fantini (2019). Figure 2 shows SDHs for seven Return Periods obtained applying the procedure described in section 2.2 for a station on the Tanaro river, a tributary of the Po river. 


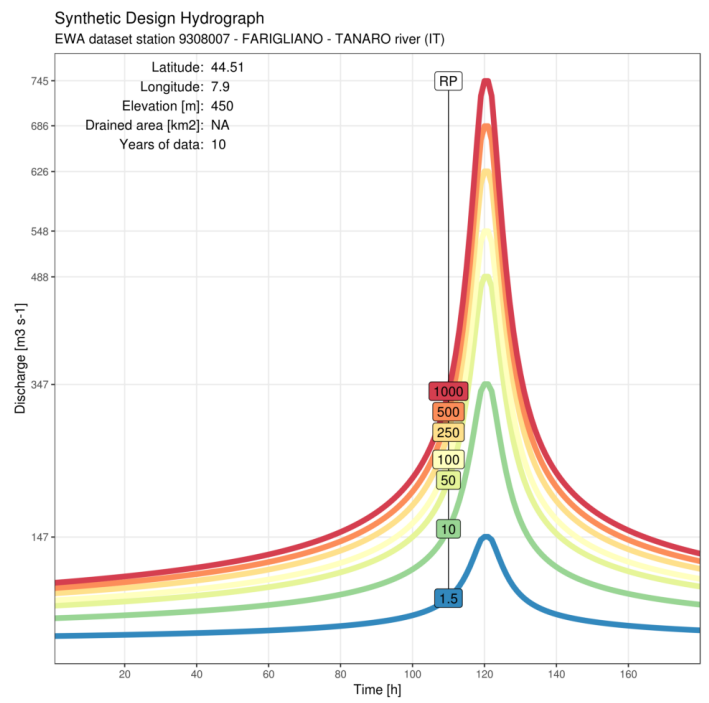

Figure 2: Example Synthetic Design Hydrograph computed following the procedure described in section 2.2 for a station on the Tanaro River, tributary of the Po river. Seven Return Periods (1.5, 10, 50, 100, 250, 500 and 1000 years) are shown.

\subsection{Modelling the flood inundation: the hydraulic model}

Floodplain hydraulic simulations are performed with a modified version of the 2D hydraulic cellular automata model CA2D. The model, described and validated in Dottori and Todini (2011), is based on a simple cell-centred finite volume scheme, which uses the Euler explicit scheme for the integration in time. The momentum equation is solved for each time step, computing volume exchanges between grid cells along the cell's borders. Volumes of each cell are successively updated using volume conservative equations. For this study, the model is run using the semi-inertial formulation of the momentum equation (Bates et al. (2010)), which allows to reproduce channel and floodplain flow processes with a good level of detail with a considerably reduced computational effort (Dottori and Todini, 2011).

The model version $\mathrm{CA}_{2} \mathrm{D}_{\text {par }}$ has been written using Fortran90 standard and it has the original model described in Dottori and Todini (2011) as a starting point. The physics is represented on a cartesian 2D grid that allows a good level of scalability. The parallel code has been carried out using the message passing interface (MPI) communications. A number of subroutines has been introduced in the code to deal with the parallelization and are compiled as separated modules. The parallelization of the code increases as expected the performance of the model which is up to 7.5 times faster respect to the original, even with a limited number of cores (Fig. 3).

The flood inundation extent is dependent on the spatial extent of the performed hydraulic simulations, and it is therefore important to define the number and location of the hydraulic 


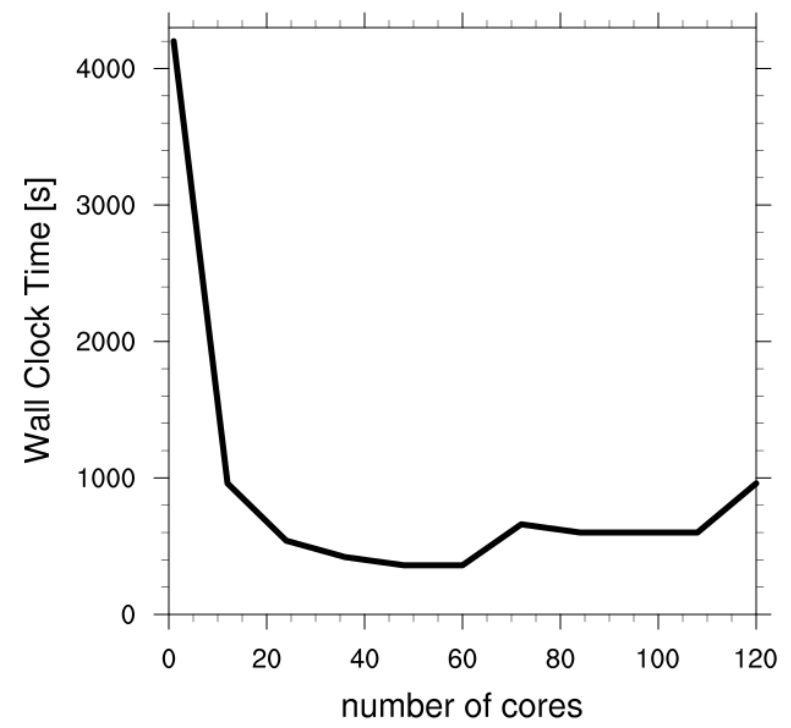

Figure 3: Wall-clock time (s) variation with the number of cores achieved with the parallelization of the CA2D model. 
simulation in order to achieve the full coverage of the interested river network. The following section will show the results obtained and it is organised in three steps: 1) calculation of the design flood hydrographs for the available observational stations along the river network using observational data, 2) calculation of the design flood hydrographs obtained using the CHyM model data on the same locations, and comparison of the two series of hydrographs for a validation of the hydraulic model along the Po river, 3) calculation of the design flood hydrographs in selected points along the river network at regular distance from each other and performance of the $\mathrm{CA}_{2} \mathrm{D}_{\text {par }}$ simulations using the $\mathrm{SDH}$ as inputs.

\subsection{The production of the flood maps.}

Currently the Shuttle Radar Topography Mission (SRTM) digital elevation model (Farr et al., 2007; Rabus et al., 2003) is considered as one of the best openly available data set for flood modeling offering near-global converage (Hirt et al., 2010; Jing et al., 2014). The void-filled HydroSHEDS variant of SRTM was used in this work with 3 arc sec resolution (Lehner et al., 2006, 2008).

As described in Neal et al. (2012) and Sampson et al. (2015) the inclusion of a river channel network is necessary to guarantee acceptable results in the simulation of flood depths and extent. River widths and depths are however difficult parameters to estimate as it is not possible to measure them remotely on large scales. Natural and artificial river defenses are also challenging to incorporate as their features are smaller than the model grid resolution (Sampson et al., 2015). Moreover their spatial distribution on large scales is not available as literature about fluvial flood defenses generally refers to individual sites (e.g. Brandimarte and Di Baldassarre, 2012; Te Linde et al., 2011). Available remotely sensed data were recently used to generate regional to global estimates of river widths and depths (Andreadis et al., 2013; Gleason and Smith, 2014) by coupling river network data to web based imagery services such as Google maps or Bing maps.

In this study we have used the near-global database of bankfull depths, based on hydraulic geometry equations and the HydroSHEDS hydrography data set described in Andreadis et al. (2013), to estimate the channel conveyance. The idea is to link the channel geometry to the discharge return period, as it guarantees that channels, properly sized, are able to contain the simulated flows and moreover mitigates against the problem of missing information about the river banks. We have used the river bankfull depths information to reshape the HydroSHEDS digital elevation model by assuming a bankfull discharge return period of 1.5 years (Leopold, 1994; Harman et al., 2008; Andreadis et al., 2013; Sampson et al., 2015; Neal et al., 2012). In order to include information about the geometry of the river, the natural and man-made banks, we used the bankfull depths to artificially "dig" the HydroSHEDS DEM until we obtained a no-flood map correspondent to the return period of 1.5 years, which represents the conveyance capacity of the river channel.

As stated in 2.1 a 15-years continuous discharge time series with Italian coverage is generated using the CHyM hydrological model from January 2001 to December 2016. Floodpeaks with $50,100,500$ year return period are derived for each river point in the model and downscaled 
to the river network at 3 arc sec resolution. Design flood hydrographs are then used to perform small scale floodplain hydraulic simulation on points which will be hereafter referred to as "virtual stations" (see Fig. 4), located every $10 \mathrm{~km}$ along the river network, for rivers with drainage areas larger than $\mathrm{A}=5 \mathrm{~km}^{2}$, using the hydraulic model $\mathrm{CA} 2 \mathrm{D}_{\text {par }}$. For each virtual station the simulation was run over a sub-domain, $0.3^{\circ} \times 0.3^{\circ}$, chosen to optimise the computational effort, as the simulation time is strongly affected by the size of the domain. For each return period a total of 474 simulations were performed and merged to produce a Western Po river flood hazard map (Fig. 5).
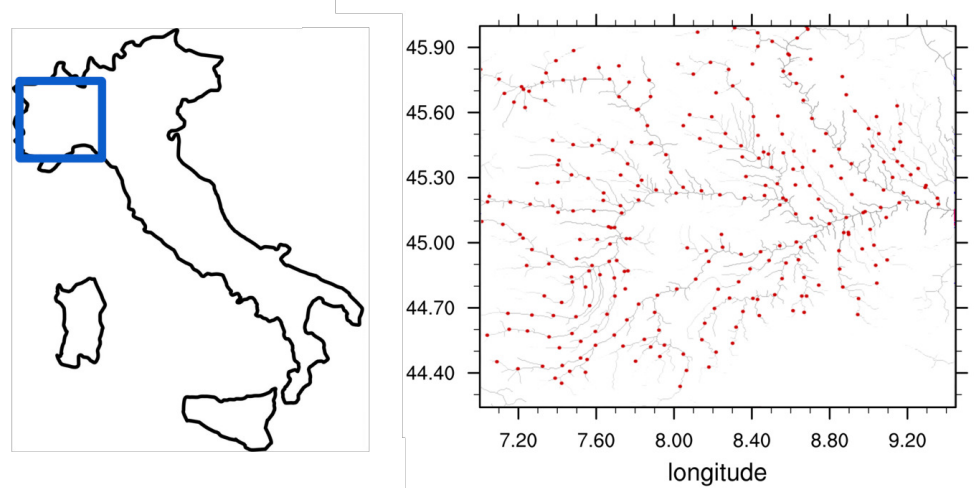

Figure 4: Virtual stations selected for drainage areas larger than $\mathrm{A}=5 \mathrm{~km}^{2}$ and regularly spaced every $10 \mathrm{~km}$ along the high-resolution river network of the analyzed domain (blue box on the left).

\section{Results}

\subsection{Validation of the SDHs.}

Tuning and testing of the method were performed on the upper Po basin, due to previous experience with the hydrological model on this domain (Coppola et al., 2014), availability of reliable observed discharge data, and lack of large water management structures. Due to the relatively small size of the simulated domains, the duration of all flood simulations was set to $240 h$. The SDHs were validated using data from the CHyM model and observations from 31 gauge stations along the Po river. Figure 6 shows the results of the comparison between the SDHs obtained with observational data and those obtained with modelled data. The SDHs are generally closely approximated by the model, both in the peaks and in the area of the curves. The coefficient of determination $\left(R^{2}\right)$ is 0.85 for the SDHs areas and 0.92 for the SDHs peaks which are the same values reported in Rojas et al. (2011) for a hydrological model of Europe without bias correction of climate data and in Paprotny et al. (2017). 


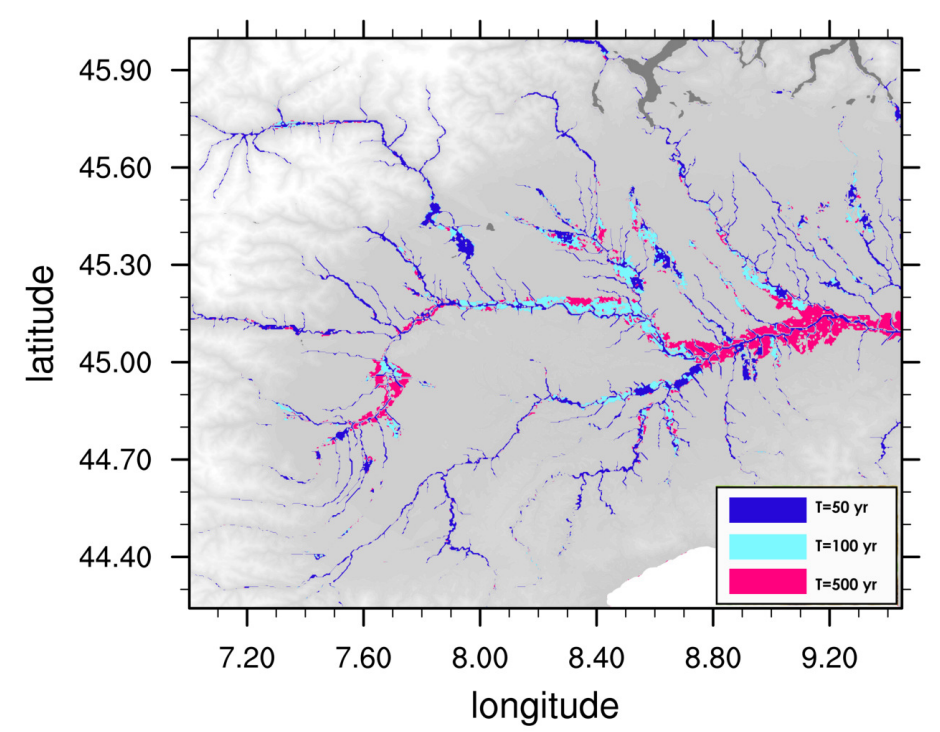

Figure 5: Western Po river flood hazard map for the Return Periods of 500, 100 and 50 years.
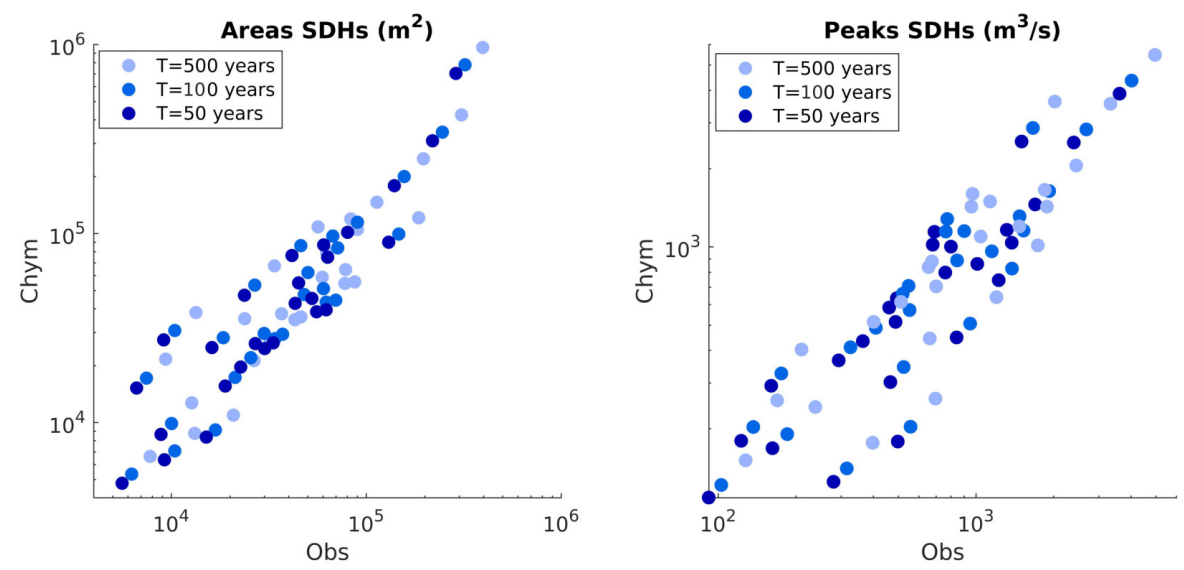

Figure 6: Comparison of simulated (CHyM) and observed (Obs) SDHs areas (a) and discharges peaks (b) for 31 gauge stations along the Po river, for three return periods. 


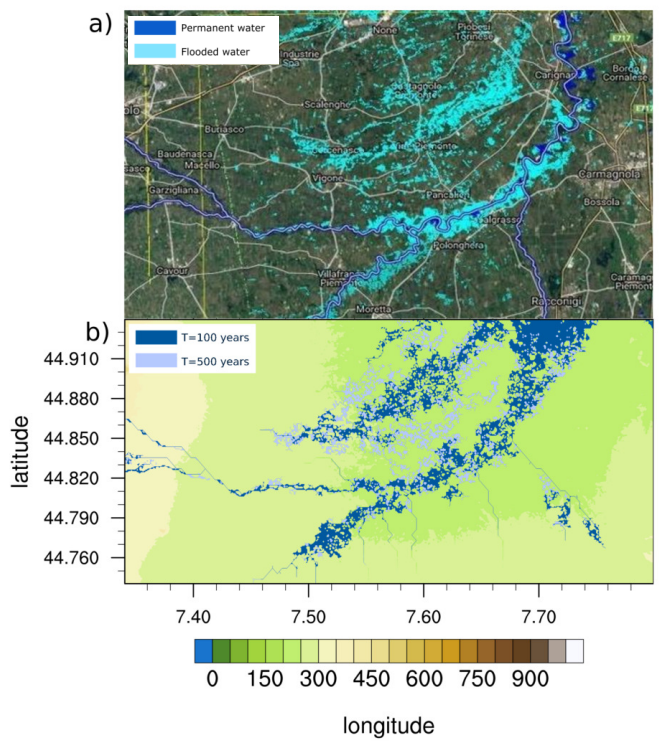

\subsection{Comparison against observations: a case study}

Validation of flood hazard models is achieved trough the evaluation of the model accuracy in estimating the probability of flood occurrence and the evaluation of relevant hazard variables of an event (e.g. flood extent and depth, flow velocity). Unfortunately the evaluation is strongly limited by the scarce availability of reference flood maps and flood observations and is a key topic in flood risk analysis. Various methods were suggested by previous studies. One consists in comparing the produced maps with previous maps based on statistical estimation of peak discharges (Pappenberger et al., 2012); another method performs a qualitative assessment of the flood events against satellite flood images (Rudari et al., 2015).

Figure 7: Case studies in November 2016, used for the validation of the method: panels above show floods as acquired by the satellite COSMO-SkyMed (COSMO-SkyMed Image (C)ASI (2016). All rights reserved). Panels below show floods as modelled by the integrated CHyM-CA2D $\mathrm{D}_{\text {par }}$ method. Panels (a) and (b) show flooded areas in the south of Turin. Panels (c) and (d) show flooded areas in the area of Alessandria.

In order to perform a first validation of the flood hazard mapping methodology we consider a case study of a flood recently occurred in Northern Italy, catalogued as an event with return period of 100 years. November 2016 was characterized by a heavy rainfalls event involving the territory of North West of Italy, in particular the Regions of Piemonte and Liguria. The bad 
weather conditions and the persistence of precipitations caused the increase of hydrometric levels of all the rivers in particular in the Po river basin.

Figures 7 (a) and (c) show the images from satellite COSMO-SkyMed (CSK) (Covello et al., 2010), a four-satellite constellation which gives the possibility of acquiring X -band Synthetic Aperture Radar (SAR) data day and night, regardless of weather conditions and is fully operational since the 2008. It provides radar data characterized by short revisit time and therefore useful for flood mapping evaluation. The lower panels show the flood maps corresponding to two different return periods $(\mathrm{T}=500$ and $\mathrm{T}=100$ years). We can see that the observed event, associated to a return period of 100 years, is fairly good represented by the model (Fig. 7 (b) and (d)) as the maps include the particular events observed.

\subsection{Comparison against existing flood hazard maps}

Another approach for the validation is to perform an evaluation against existing highresolution flood hazard maps (Alfieri et al., 2013; Sampson et al., 2015; Winsemius et al., 2016). The evaluation of simulated flood maps against reference maps is performed using the indexes proposed in literature (Dottori et al., 2016d; Bates and De Roo, 2000; Alfieri et al., 2014). The Hit Ratio index (HR), defined as:

$$
H R=\left(F_{m} \cap F_{o}\right) /\left(F_{o}\right)
$$

evaluates the agreement of modelled maps $\left(F_{m}\right)$ with existing maps $\left(F_{o}\right)$. This index does not take into account the overprediction and underprediction of the flooded area, therefore two other measures are calculated to account for this: the False Alarm index (FA), defined as

$$
F A=\left[F_{m}-\left(F_{m} \cap F_{o}\right)\right] /\left(F_{o}\right)
$$

where $F_{m}-\left(F_{m} \cap F_{o}\right)$ is the flooded area wrongly predicted by the model, and the Critical Success index (CS), defined as:

$$
C S=\left(F_{m} \cap F_{o}\right) /\left(F_{m} \cup F_{o}\right) .
$$

The produced flood hazard maps, hereinafter referred to as "CA2D maps", are tested against the official hazard AdbPo flood maps (http://www.adbpo.gov.it), produced by the River Po Authority, who classifies the flood plain of the Po river into three levels corresponding to return periods of 20-50 years (high frequency), 100-200 years (medium frequency) and 500 years (low frequency).

In addition, we compare the CA2D maps with the flood hazard maps produced by the Joint Research Centre of the European Commission (JRC). The JRC maps are freely available online and are based on streamflow data from the European Flood Awareness System (EFAS (Demeritt et al., 2013) and also calculated with a spatial resolution of 3" (Dottori et al., 2016a,b,c). To perform the indexes calculations, we have focused our analysis on a smaller 

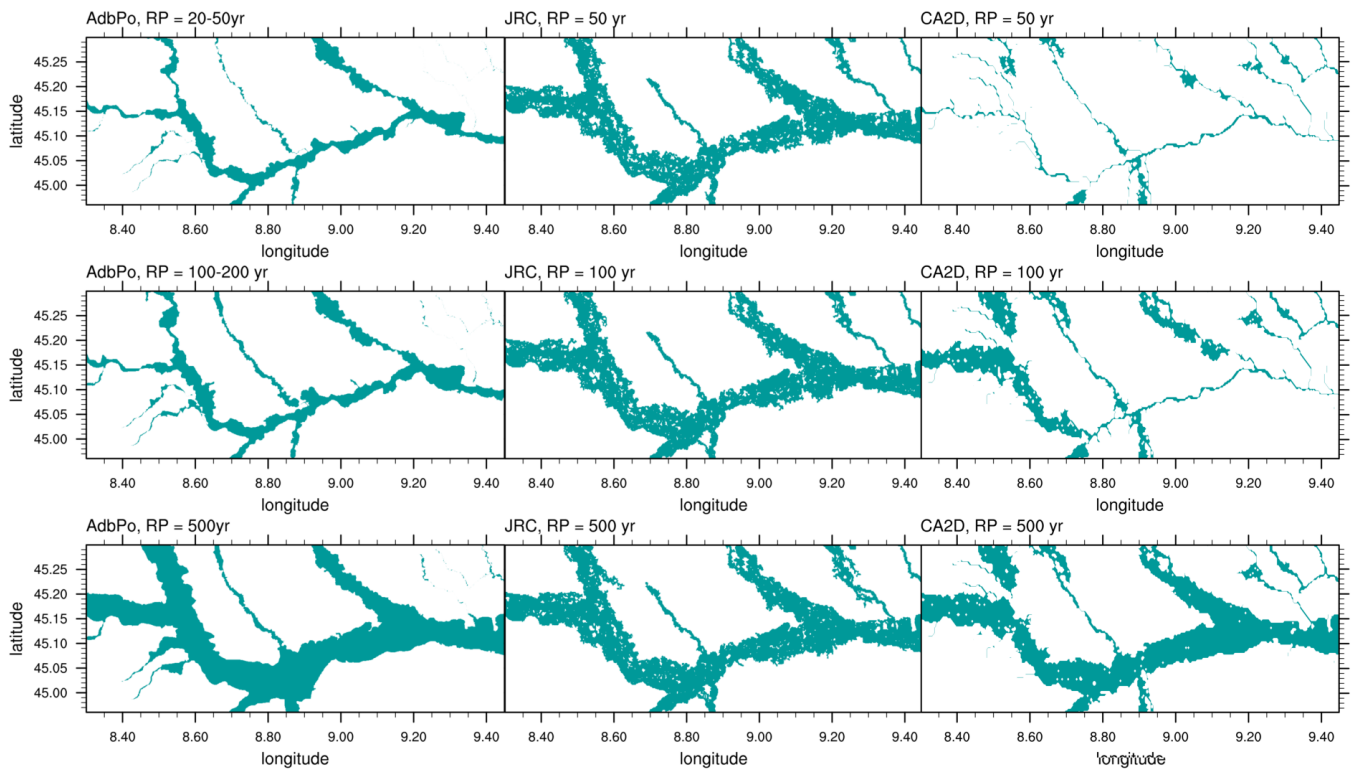

Figure 8: Adbpo, JRC and CA2D flood hazard maps for the 50 years return period (upper panels), 100 years return period (central panels) and 500 years return period (lower panels) 
portion of the domain, centred on the main river, removing flooded areas originating from river sections with an upstream area smaller than $500 \mathrm{~km}^{2}$ since they are not simulated and therefore not included in the JRC maps. The JRC flood maps used for the comparison do not consider flood defences and river geometry, for this reason we only calculate the performance indices (Eq. (7), (8) and (9)) for the 500 years return period, reported in Table 1. Indices are calculated for the CA2D and JRC maps $\left(F_{m}\right)$ against the Adbpo maps $\left(F_{o}\right)$.

\begin{tabular}{|l|c|c|c|}
\hline & Hit Rate & False Alarm & Critical Success \\
\hline JRC & 0.83 & 0.15 & 0.73 \\
CA2D & 0.76 & 0.12 & 0.67 \\
\hline
\end{tabular}

Table 1: Evaluation of the CA2D and JRC flooded extent against official flood hazard maps (Adbpo) for thre return period of 500 years.

As can be seen, the CA2D maps provide fairly good results for the 500 years return period, with a HR of 0.76 , a CS index of 0.67 and a very low false alarm value $(0.12)$, while results are less satisfactory for lower return periods, with considerable underestimation of flood extent respect to the offical maps (see Fig. 8). JRC maps also show fair results for the 500 years return period, with a HR of 0.83 , a CS of 0.73 and FA of 0.15 , and are similar to CA2D maps (Fig. 9), but they systematically overestimate flood extent for the lower return periods (see Fig. 8). The differences between modelled and official maps are partly due to the topography of the Po floodplain, which is not reproduced in the STRT used by both JRC and CA2D maps. Indeed, the area enclosed by the main levees has a complex system of minor embankments, which are designed for lower flood return periods than the main levees (Castellarin et al., 2011). This explains why AdBPo maps are quite similar for return periods of 20-50 years and 100-200 years (see Figure 8).

The narrow extent of flooded areas for return periods of 50 and 100 years in sectors of the river network suggests that the channel conveyance may be overestimated in CA2D maps. However also our reference AdBPo maps show very similar flood extents for return periods of 20-50 and 100-200 years as explained above, therefore the CA2D underestimation can not be quantified. Future work will anyway refine the methodology of channel "digging". This is indeed an open research question, due to the absence of large-scale methods or datasets to estimate river channel depth (Dottori et al., 2016d). Nevertheless, it is worth noting that the method presented here improves the sensitivity to return period of flood extent maps. Conversely, JRC maps calculated for different return period have limited differences, due to the absence of river geometry details. These results confirm that the inclusion of a river channel network is necessary to guarantee acceptable results in the simulation of flood depths and extent for all return periods (Neal et al., 2012). 


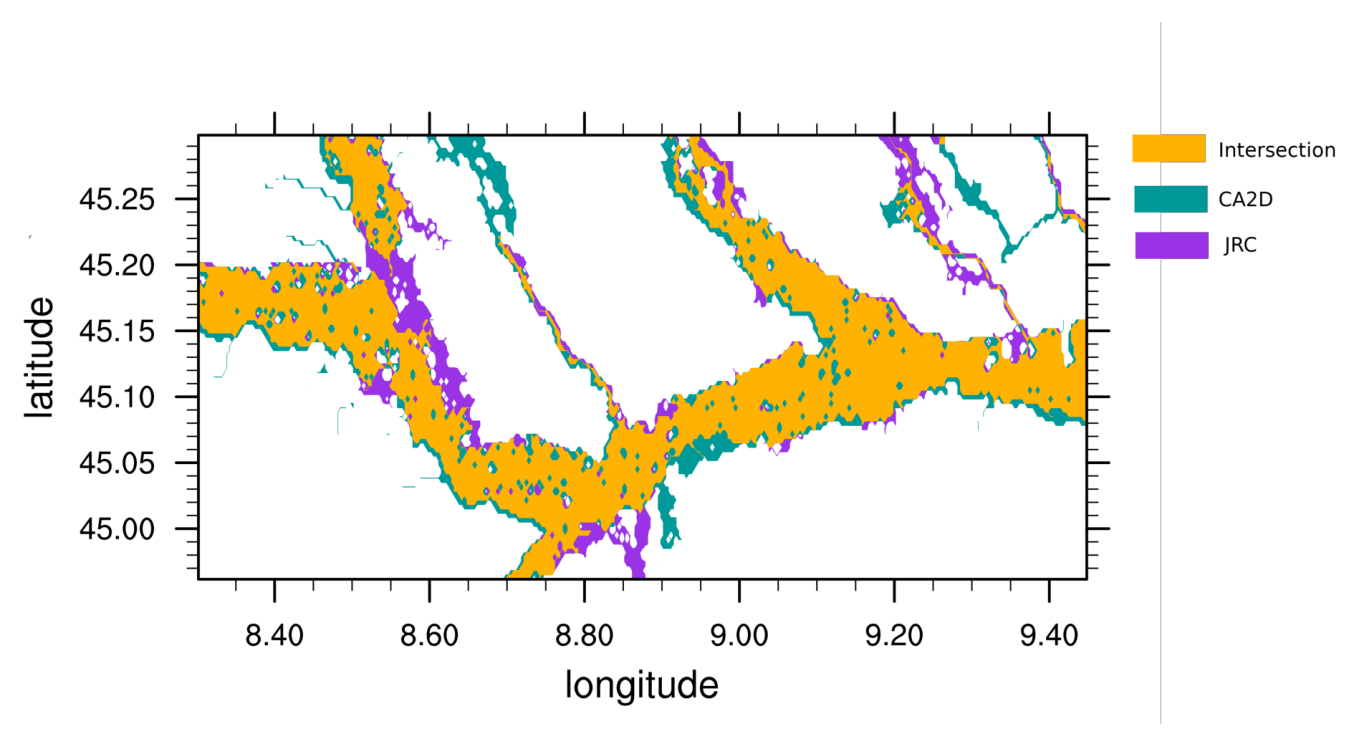

Figure 9: CA2D and JRC flood hazard maps for the 500 years return period

\section{Conclusions}

In this paper we investigate the feasibility of producing high-resolution flood maps using an innovative approach which reshapes the digital elevation models by simulating a "digging " assuming that no floods take place for discharges associated to the return period of 1.5 years, representing the conveyance capacity of the river channel. The main purpose of this method development is to be able to apply it also in those regions where there are no available information about river natural and man-made banks. A 2-dimensional hydraulic model is used to simulate the propagation of the hydrographs across the HydroSHEDS void filled DEM, which was processed to yield an estimate of bankfull discharge. The evaluation of the produced flood maps was performed through some case studies of observed flood extent satellite data, and through existing flood maps over the entire domain, showing a good spatial agreement with observations for high return periods. Comparison for lower return periods showed that the DEM-reshaping method improves the sensitivity to return period of flood extent maps but needs further improvement, for instance, combining observed data about river bed depth and width and discharge (Yamazaki et al., 2014). The validation of the method in a region where all the hydrological and hydraulic information are available will allow us to extend the method elsewhere. 


\section{Acknowledgments}

The authors gratefully acknowledge the financial support of the Allianz Insurance Company for the realization of this project.

\section{References}

Alfieri, L., Burek, P., Dutra, E., Krzeminski, B., Muraro, D., Thielen, J., and Pappenberger, F.: GloFAS-global ensemble streamflow forecasting and flood early warning, Hydrology and Earth System Sciences, 17, 1161, 2013.

Alfieri, L., Salamon, P., Bianchi, A., Neal, J., Bates, P., and Feyen, L.: Advances in panEuropean flood hazard mapping, Hydrological processes, 28, 4067-4077, 2014.

Alfieri, L., Burek, P., Feyen, L., and Forzieri, G.: Global warming increases the frequency of river floods in Europe, Hydrology and Earth System Sciences, 19, 2247-2260, 2015.

Andreadis, K., Schumann, G., and Pavelsky, T.: A simple global river bankfull width and depth database, Water Resources Research, 49, 7164-7168, 2013.

Austin, R., Chen, A., Savic, D., and Djordjevic, S.: Fast Simulation of Sewer Flow using Cellular Automata, NOVATECH 2013, 2013.

Bárdossy, A.: Calibration of hydrological model parameters for ungauged catchments, Hydrology and Earth System Sciences Discussions, 11, 703-710, 2007.

Bates, P. and De Roo, A.: A simple raster-based model for flood inundation simulation, Journal of Hydrology, 236, 54-77, 2000.

Bates, P., Horritt, M., Smith, C., and Mason, D.: Integrating remote sensing observations of flood hydrology and hydraulic modelling, Hydrological Processes, 11, 1777-1795, 1997.

Bates, P., Horritt, M., and Fewtrell, T.: A simple inertial formulation of the shallow water equations for efficient two-dimensional flood inundation modelling., Journal of Hydrology, 387, 33-45, 2010.

Bianco, L., Tomassetti, B., Coppola, E., Fracassi, A., Verdecchia, M., and Visconti, G.: Thermally driven circulation in a region of complex topography: Comparison of windprofiling radar measurements and MM5 numerical predictions, Annales Geophysicae, doi: 10.5194/angeo-24-1537-2006, 2006.

Brandimarte, L. and Di Baldassarre, G.: Uncertainty in design flood profiles derived by hydraulic modelling, Hydrology Research, 43, 753-761, 2012. 
Brunner, G.: Hec-ras (river analysis system), in: North American Water and Environment Congress \& Destructive Water, pp. 3782-3787, ASCE, 2002.

Castellarin, A., Di Baldassarre, G., and Brath, A.: Floodplain management strategies for flood attenuation in the river Po, River Research and Applications, 27, 1037-1047, 2011.

Coppola, E., Tomassetti, B., Mariotti, L., Verdecchia, M., and Visconti, G.: Cellular automata algorithms for drainage network extraction and rainfall data assimilation, Hydrological Sciences Journal, 52, 579-592, 2007.

Coppola, E., Verdecchia, M., Giorgi, F., Colaiuda, V., Tomassetti, B., and Lombardi, A.: Changing hydrological conditions in the Po basin under global warming, Science of the Total Environment, 493, 1183-1196, 2014.

Coulthard, T., Hicks, D., and Van De Wiel, M.: Cellular modelling of river catchments and reaches: advantages, limitations and prospects, Geomorphology, 90, 192-207, 2007.

Covello, F., Battazza, F., Coletta, A., Lopinto, E., Fiorentino, C., Pietranera, L., Valentini, G., and Zoffoli, S.: COSMO-SkyMed an existing opportunity for observing the Earth, Journal of Geodynamics, 49, 171-180, 2010.

Demeritt, D., Nobert, S., Cloke, H. L., and Pappenberger, F.: The European Flood Alert System and the communication, perception, and use of ensemble predictions for operational flood risk management, Hydrological Processes, 27, 147-157, 2013.

Dottori, F. and Todini, E.: Developments of a flood inundation model based on the cellular automata approach: testing different methods to improve model performance, Physics and Chemistry of the Earth, Parts A/B/C, 36, 266-280, 2011.

Dottori, F., Alfieri, L., Salamon, P., Bianchi, A., Feyen, L., and Lorini, V.: Flood hazard map for Europe, 100-year return period, European Commission, Joint Research Centre (JRC)[Dataset] PID: http://data. europa. eu/89h/jrc-floods-floodmapeu_rp100y-tif, 2016a.

Dottori, F., Alfieri, L., Salamon, P., Bianchi, A., Feyen, L., and Lorini, V.: Flood hazard map for Europe, 50-year return period, European Commission, Joint Research Centre (JRC)[Dataset] PID: http://data. europa. eu/89h/jrc-floods-floodmapeu_rp50y-tif, 2016b.

Dottori, F., Alfieri, L., Salamon, P., Bianchi, A., Feyen, L., and Lorini, V.: Flood hazard map for Europe, 500-year return period, European Commission, Joint Research Centre (JRC)[Dataset] PID: http://data. europa. eu/89h/jrc-floods-floodmapeu_rp500y-tif, 2016c.

Dottori, F., Salamon, P., Bianchi, A., Alfieri, L., Hirpa, F., and Feyen, L.: Development and evaluation of a framework for global flood hazard mapping, Advances in water resources, 94, 87-102, 2016d.

European Commission: Directive 2007/60/EC of the European Parliament and of the Coun- 
cil of 23 October 2007 on the assessment and management of flood risks, J. Eur. Union, L 288, 27-34, 2007.

Fantini, A.: Climate change impact on flood hazard over Italy, Ph.D. thesis, University of Trieste, 2019.

Fantini, A., Coppola, E., Verdecchia, M., and Giuliani, G.: GRIPHO : a gridded highresolution hourly precipitation dataset over Italy, in preparation, 2019.

Farr, T., Rosen, P., Caro, E., Crippen, R., Duren, R., Hensley, S., Kobrick, M., Paller, M., Rodriguez, E., Roth, L., et al.: The shuttle radar topography mission, Reviews of geophysics, 45, 2007.

Fread, D.: Channel routing, Hydrological forecasting, pp. 437-503, 1985.

Galland, J.-C., Goutal, N., and Hervouet, J.-M.: TELEMAC: A new numerical model for solving shallow water equations, Advances in Water Resources, 14, 138-148, 1991.

Gleason, C. and Smith, L.: Toward global mapping of river discharge using satellite images and at-many-stations hydraulic geometry, Proceedings of the National Academy of Sciences, 111, 4788-4791, 2014.

Grell, G., Dudhia, J., and Stauffer, D.: A description of the fifth-generation Penn State/NCAR Mesoscale Model (MM5), Tech. Rep. December, doi:10.5065/D60Z716B, 1994.

Harman, C., Stewardson, M., and DeRose, R.: Variability and uncertainty in reach bankfull hydraulic geometry, Journal of hydrology, 351, 13-25, 2008.

Havnø, K., Madsen, M., and Dørge, J.: MIKE 11-a generalized river modelling package, Computer models of watershed hydrology, pp. 733-782, 1995.

Hirt, C., Filmer, M., and Featherstone, W.: Comparison and validation of the recent freely available ASTER-GDEM ver1, SRTM ver4. 1 and GEODATA DEM-9S ver3 digital elevation models over Australia, Australian Journal of Earth Sciences, 57, 337-347, 2010.

Jing, C., Shortridge, A., Lin, S., and Wu, J.: Comparison and validation of SRTM and ASTER GDEM for a subtropical landscape in Southeastern China, International Journal of Digital Earth, 7, 969-992, 2014.

Khan, S., Hong, Y., Wang, J., Yilmaz, K., Gourley, J., Adler, R., Brakenridge, G., Policelli, F., Habib, S., and Irwin, D.: Satellite remote sensing and hydrologic modeling for flood inundation mapping in Lake Victoria basin: Implications for hydrologic prediction in ungauged basins, IEEE Transactions on Geoscience and Remote Sensing, 49, 85-95, 2011.

Krupka, M., Pender, G., Wallis, S., Sayers, P., and Mulet-Marti, J.: A rapid flood inundation model, in: Proceedings of the Congress-International Association for Hydraulic Research, vol. 32 , p. $28,2007$. 
Lehner, B., Verdin, K., and Jarvis, A.: HydroSHEDS technical documentation, version 1.0, World Wildlife Fund US, Washington, DC, pp. 1-27, 2006.

Lehner, B., Verdin, K., and Jarvis, A.: New global hydrography derived from spaceborne elevation data, Eos, Transactions American Geophysical Union, 89, 93-94, 2008.

Lehner, B., Verdin, K., and Jarvis, A.: HydroSHEDS Technical Documentation Version 1.2, EOS Transactions, 2013.

Leopold, L.: A View of the River, Harvard University Press, 1994.

Lighthill, M. and Whitham, G.: On Kinematic Waves. I. Flood Movement in Long Rivers, Proceedings of the Royal Society A: Mathematical, Physical and Engineering Sciences, doi:10.1098/rspa.1955.0088, 1955.

Maione, U., Mignosa, P., and Tomirotti, M.: Regional estimation model of synthetic design hydrographs, International Journal of River Basin Management, 12, 151-163, 2003.

Merz, R. and Blöschl, G.: Flood frequency regionalisation?spatial proximity vs. catchment attributes, Journal of Hydrology, 302, 283-306, 2005.

Moel, H. d., Alphen, J. v., Aerts, J., et al.: Flood maps in Europe-methods, availability and use, Nat. Hazards Earth Syst. Sci., 9, 2009.

Montanari, A.: Hydrology of the Po River: looking for changing patterns in river discharge, Hydrology and Earth System Sciences, 16, 3739-3747, 2012.

Neal, J., Schumann, G., and Bates, P.: A subgrid channel model for simulating river hydraulics and floodplain inundation over large and data sparse areas, Water Resources Research, 48, 2012.

NERC, N. E. R. C. G. B.: Flood Studies Report in Five Volumes, NERC, 1975.

Pappenberger, F., Dutra, E., Wetterhall, F., and Cloke, H.: Deriving global flood hazard maps of fluvial floods through a physical model cascade, Hydrology and Earth System Sciences, 16, 4143-4156, 2012.

Paprotny, D., Morales-Nápoles, O., and Jonkman, S.: Efficient pan-European river flood hazard modelling through a combination of statistical and physical models, Natural Hazards and Earth System Sciences, 17, 1267, 2017.

Rabus, B., Eineder, M., Roth, A., and Bamler, R.: The shuttle radar topography mission - a new class of digital elevation models acquired by spaceborne radar, ISPRS journal of photogrammetry and remote sensing, 57, 241-262, 2003.

Rojas, R., Feyen, L., Dosio, A., and Bavera, D.: Improving pan-European hydrological simulation of extreme events through statistical bias correction of RCM-driven climate simulations., Hydrology \& Earth System Sciences, 15, 2011. 
Rudari, R., Silvestro, F., Campo, L., Rebora, N., Boni, G., and Herold, C.: Improvement of the Global Food Model for the GAR 2015, United Nations Office for Disaster Risk Reduction (UNISDR), Centro Internazionale in Monitoraggio Ambientale (CIMA), UNEP GRID-Arendal (GRID-Arendal): Geneva, Switzerland, p. 69, 2015.

Sampson, C., Smith, A., Bates, P., Neal, J., Alfieri, L., and Freer, J.: A high-resolution global flood hazard model, Water resources research, 51, 7358-7381, 2015.

Samuels, P.: Cross section location in one-dimensional models, in: International Conference on River Flood Hydraulics, Wiley, Chichester, pp. 339-350, 1990.

Te Linde, A., Aerts, J., and van den Hurk, B.: Effects of flood control measures and climate change in the Rhine basin, in: Proceedings of the 4th International Symposium on Flood Defence, Toronto, Canada, pp. 6-5, 2008.

Te Linde, A., Bubeck, P., Dekkers, J., De Moel, H., and Aerts, J.: Future flood risk estimates along the river Rhine, Natural Hazards and Earth System Sciences, 11, 459, 2011.

Tomassetti, B., Coppola, E., Verdecchia, M., and Visconti, G.: Coupling a distributed grid based hydrological model and MM5 meteorological model for flooding alert mapping, Advances in Geosciences, doi:10.5194/adgeo-2-59-2005, 2005a.

Tomassetti, B., Coppola, E., Verdecchia, M., and Visconti, G.: Coupling a distributed grid based hydrological model and MM5 meteorological model for flooding alert mapping, Advances in Geosciences, 2, 59-63, 2005b.

Verdecchia, M., Coppola, E., Faccani, C., Ferretti, R., Memmo, A., Montopoli, M., Rivolta, G., Paolucci, T., Picciotti, E., Santacasa, A., Tomassetti, B., Visconti, G., and Marzano, F.: Flood forecast in complex orography coupling distributed hydro-meteorological models and in-situ and remote sensing data, Meteorology and Atmospheric Physics, doi:10.1007/ s00703-007-0278-z, 2008.

Verdecchia, M., Coppola, E., Tomassetti, B., and Visconti, G.: Cetemps Hydrological Model (CHyM), a Distributed Grid-Based Model Assimilating Different Rainfall Data Sources, in: Hydrological Modelling and the Water Cycle, pp. 165-201, Springer, 2009.

Winsemius, H., Aerts, J., van Beek, L., Bierkens, M., Bouwman, A., Jongman, B., Kwadijk, J., Ligtvoet, W., Lucas, P., Van Vuuren, D., et al.: Global drivers of future river flood risk, Nature Climate Change, 6, 381, 2016.

Wolfram, S.: Cellular automata as models of complexity, Nature, 311, 419-424, 1984.

Wood, E., Roundy, J., Troy, T., Van Beek, L., Bierkens, M., Blyth, E., de Roo, A., Döll, P., Ek, M., Famiglietti, J., et al.: Hyperresolution global land surface modeling: Meeting a grand challenge for monitoring Earth's terrestrial water, Water Resources Research, 47, 2011.

Yamazaki, D., O'Loughlin, F., Trigg, M. A., Miller, Z. F., Pavelsky, T. M., and Bates, P. D.: 
544 Development of the global width database for large rivers, Water Resources Research, 50, $545 \quad 3467-3480,2014$.

${ }_{546}$ Zhao, D., Shen, H., Tabios III, G., Lai, J., and Tan, W.: Finite-volume two-dimensional ${ }_{547}$ unsteady-flow model for river basins, Journal of Hydraulic Engineering, 120, 863-883, $548 \quad 1994$. 